\section{Problems Facing the Young of Today}

\section{Or, the Young of Yesterday?}

Franklin has been reading past issues of Europhysics News. One article particularly caught his eye. It was about the careers of physicists and had some excellent ideas on improving career prospects and links with industry. One such idea was that the European Physical Society help students to supplement their studies by spending time working in the industry of another country-work placements on a European scale. This project would suit the Society perfectly; it demands an international perspective, gives a boost to the career prospects of students and increases their mobility in addition.

The article had other ideas. Physics courses should include "notions of economics" to give students "some understanding of the boundary conditions within which they will work" (which presumably refers to financial skills rather than notions of econophysics). For maturer physicists, the article recommends that university professors spend sabbatical years in industry, and that industrial physicists temporarily occupy positions in higher education.

There's more, about giving academics management training so they can penetrate smaller industries. There's strong advice for national societies, too:

"Societies should be transformed from the learned societies fashioned on the pattern of the 19th Century to modern centres of action, welcoming an industrial membership."

The message is clear. Careers in industry should be virtually interchangeable with those in academia. Good advice for today. But the article is not recent.

Franklin had to go back sixteen years to find it (December 1981). It's a report on a seminar, held by the Advisory Committee on Physics and Society, which deliberated in June 1981.

When articles of the past give advice that is good for today, it poses the question of how we measure progress. Franklin suspects that if, with his cheeky sense of humour, he had presented the ideas as if they were from a recent article, they would have had less impact.

The meeting of November 1981 , it is clear from reading the proceedings, was sustained by foresight and clear thinking and benefited from a distinguished and capable organizing committee (including, among others, P. Averbach who founded the Association Bernard Grégory which helps $\mathrm{PhD}$ students to find jobs).

If a second meeting were to be held, 18 years on, it would probably review the changes of the last few years: more universities now include a management course with science studies; many national physical societies have maintained and encouraged industrial membership. But is this enough, should we have done more? Eighteen years is a long time, especially when there is a need to help young physicists. It is certainly long enough for many to leave physics, or choose not to study physics, if career prospects are bad.

Well intentioned, well organized conferences on topics as important as this are not enough if there is no objective means of remembering their conclusions. One person who has an excellent memory for EPS meetings is the outgoing Secretary General, Gero Thomas. He remembers the meeting, and dug out the proceedings from the archives when approached by Franklin. (They are available at the Secretariat if anyone wishes to consult them.) Unfortunately, with the next issue of the magazine, $\mathrm{Mr}$ Thomas will have left the EPS, and will no longer be available for remembering past events.

Franklin wants to propose a measurement function. Or rather, the idea of one. Meetings are no good unless they set tasks to be achieved and declare when progress is to be assessed. This should enable a qualitative measurement function: details of what should happen when can be used to measure progress. It would also enable us to search for the reasons why old ideas are still new, and why good intentions haven't turned into accomplishments. Moreover, it would help us to remember the time and energy that had been spent by conference organizers and participants.

In the future, meetings should be followed by or include a workshop which plans how to put ideas into action. Then, if dreams are not turned into actions, anyone can sit down and work out why not: 'Okay, this is what was meant to happen; what went wrong?' Worthy meetings should never risk becoming just memories, or archives.

Franklin would like to hear from anyone who remembers the meeting, and from anyone who agrees or disagrees with his views. Write to Franklin, c/o European Physical Society, BP 2136, F-68060 Mulhouse Cedex; or e-mail eneditor@univ-mulhouse.fr
"Ever since Osborne Reynolds strolled on the beach in 1885 and studied the imprint of his foot we have been aware that sand is not simple." Jam Session page 45

"I even managed to sit opposite a Romanian girl who was about to start a PhD in the same field as me.Considering that there were just 240 people at the conference, and far infrared/ sub-millimetre research is in its infancy, this was no mean feat." Vienna, 1997 page 57

\section{0 events for you calen- dar, including forthcom- ing EPS meetings, start} page 62

second masthead

Executive Editor David Lee Contributing Editor Denis Weaire

Thank-you Marie Blandine, Gero Thomas Europhysics News is in the process of recruiting correspondents in all areas of physics and related activities. If you wish to contribute to $E N$ contact the editorial office as soon as possible 